\title{
ARCHITECTURE, ASTRONOMY, AND SACRED SPACE: THE CASE OF THE AVENUE OF THE SPHINXES
}

\author{
Giulio Magli \\ Politecnico di Milano \\ P.le Leonardo da Vinci 32, 20133 Milan, Italy \\ Giulio.Magli@Polimi.it
}

At Thebes, today' Luxor, two among the most magnificent temples of humanity were built: Karnak, which was the "house" of Amun-Ra, and Luxor. Luxor was dedicated to Amun as well, but the God was worshipped there in another "form", Amenenope, the God of renewal. The two temples were connected by a processional avenue, the so-called Avenue of the Sphinxes. Archaeoastronomy is used here to investigate on cognitive aspects of the Luxor-Karnak relationship and, especially, on the role of the Avenue in this relationship.

\section{Introduction}

Two among the most magnificent temples ever built are located along the eastern bank of the river Nile in today's Luxor: the so called Karnak and Luxor temples, by far the most important sacred places of Egypt during the New Kingdom (Wilkinson 2003).

Both monuments were devoted to Amun-Ra, the ancestral God of Thebes who once united with the Sun God - became the most important God of Egypt. Karnak - founded in the Middle Kingdom - was the official temple of Amun, his elected residence and main centre of cult. But what about Luxor? At Luxor, a "creator version" of the very same God was venerated, but the true meaning of this worship is unclear and, as a consequence, many "alternative" interpretations of this temple exist, which have little or nothing to do with the ancient Egyptian's religion and way of thinking.

Closely connected with the problem of Luxor's function and meaning is the role of the avenue of the Sphinxes, a processional way which connected it with Karnak. It is the aim of the present paper to account briefly on recent results which have been obtained on this subject within a wider research project on cognitive aspects of ancient Egyptian architecture (see Magli 2010, 2011a,b, 2014). 


\section{The Luxor-Karnak relationship}

When the Theban kings unified the country at the beginning of the Middle Kingdom, the role of Amun of Thebes started to grow in importance, and Karnak, the most select of the places, was founded in his honour (Blyth 2006). With the New Kingdom, Karnak received a series of huge, spectacular additions. In particular, Hatshepsut (the fifth ruler of the 18 dynasty) promoted the worship of a "Theban triad" of gods, formed - besides Amun - by his wife Mut and their son Khonsu, whose temples clustered near the main Karnak one. It is with the Pharaoh-queen that the sacred area of eastern Thebes definitively acquired his second, fundamental element: the so-called temple of Luxor.

Luxor is placed along the Nile some $3.5 \mathrm{~km}$ to the south-west of Karnak. Known in ancient times as the sanctuary of the south, it was again principally dedicated to Amun, worshipped as Amenenope, God of renewal and fertility. As in Karnak, also here a series of subsequent construction stages can be recognized.

The third element of the Karnak-Luxor complex is a straight processional way connecting Karnak with Luxor. It is usually referred to as the Sphinx Avenue because it is flanked by hundreds of sphinxes. The statues - most of which have been brought again to light in very recent times - are a relatively recent addition, but the avenue can be ascribed at least to Hatshepsut times if not before; the Pharaoh-queen in particular is known for the construction of six "barque stations" along it (Cabrol 2001).

All in all, it can be said that Karnak, Luxor and the Sphinx Alley form altogether a unique sacred space. The key to its meaning is provided by the Opet festival, which connected the Karnak temples with Luxor once a year (Assmann 2003). During the festival, the statues of the Theban triad literally visited Luxor. Once in Luxor they were housed in the triple shrine located inside Ramesses II' first court, on the right of the entrance. The festival commenced with the Karnak statues being loaded onto ceremonial barques under which long stakes were inserted. Baldachins were then carried on the shoulders of the priests, and the religious procession moved towards Luxor along the avenue. Renewal was the focus of this feast, and countless offerings of flowers were brought to the temples. The rites were related with the renovation of power, both divine and royal, and Luxor acted as an explicit, perennial symbol of this renewal. Public access to temples was generally forbidden, so the idea of circulating the god's statues back and forth met the need to have contact, however detached, with the gods. The Pharaoh, in accordance with his divine nature, had of course a key role, for the festival was connected with the renewal of the Ka (the vital spirit) of the king and - by extension - of that of all people. The Pharaoh himself made a reappearance, having changed his clothes, after the entrance of the procession into the recessed part of the Luxor temple. The secluded rites included a repetition of the coronation, with the king receiving the two crowns in front of the God's image and presenting special offerings. Also, the Gods themselves were "reactivated" in the festival, to the point 
that the ceremony known as "Opening of the mouth" was probably performed on their statues (Bell 1985). This ceremony was originally a funerary ritual, attested since the Old Kingdom, in which the officiant, using special tools, touched the mouth and the eyes of the mummy (or the statue) of the deceased, magically enabling it to receive food and drink, to breathe, and see.

\section{The role of astronomy}

As is very well known, the Karnak axis is aligned with the winter solstice sunrise (Hawkins 1974). The front of the temple actually points towards the Nile and the summer solstice sunset, but the setting sun cannot penetrate the temple in full, because the horizon is occupied by the Theban hills, which obstruct the view. The astronomical orientation to the winter solstice sunrise is connected with the calendar, since in the years around the foundation of Karnak the Egyptian calendar completed one half of its turnaround with respect to the solar cycle, and thus new year's day - originally at summer solstice - coincided with the winter solstice.

The astronomical orientation of the Sphinx alley has been studied in Magli (2014). The pathway proceeds very straight, so that the azimuth can be estimated quite precisely by repeated sampling along its course, and it is inter-cardinal, that is $45^{\circ}$ from Luxor to Karnak (author's data). This azimuth was not constrained by strict local topography, as the connecting avenue could have been projected within a wide range of azimuths (the arrival area was a huge open space parallel to the Nile, and the arrival point was chosen hundreds of meters to the north of the existing buildings at that time). The choice of orientation is, therefore, hardly random, and its most likely explanation is astronomical.

Inter-cardinal orientation is present in Egypt since the Early Dynastic times. The first occurrence is in Abydos, where the royal enclosures and the royal tombs of the first two dynasties at Umm el Qab are all orientated inter cardinally (Belmonte and Shaltout 2005). A inter-cardinal axis governs the general topography at Giza (Lehner 1985, Magli 2010). At Western Thebes, inter-cardinal orientation (this time NW-SE) characterizes also the majority of the funerary temples (Belmonte, Shaltout and Fekri 2009). From the astronomical point of view, inter-cardinal directions are and were out of the solar and lunar range in Egypt, but they corresponded to the Milky Way, seen as a relatively wide band in the sky (say $12^{\circ}$ wide), during the course of the 3 Egyptian kingdoms (approximatively 3200-1100 BC). The Milky Way was a very important presence in the ancient Egyptian sky. It is mentioned in the Pyramid Texts, where it likely functioned as an analogue of the "shaman's path" for the travel of the pharaoh's spirit in the afterworld sky realm, and was identified as an image of Nut, the sky Goddesses "bending" over the earth. In particular if we take as reference the date of Hatshepsut's accession for the planning of the avenue (around $1470 \mathrm{BC}$ ) we can see that many bright stars related to our galaxy were rising, and other were setting, at the two ends. The two regions of azimuths located at the two extrema (close to $45^{\circ}$ at rising and close to $225^{\circ}$ at setting) were in fact crowded by bright stars: the "northern branch" of the 
Milky Way with Cygnus, (but also Arcturus and Vega), rising to the north; the brightest part of the Milky Way - and in particular, the Southern Cross-Centaurus group - setting to the south. In particular, the spectacle of the Milky Way setting "inside" the Luxor temple, mostly visible in winter months, must have been particularly impressive. Of course, due to precession, we cannot enjoy the spectacle any more; the two centuries or so separating Hatshepsut from Ramesses II were not sufficient however for precession to destroy these phenomena so that 200 years later the same spectacle was still quite effective.

The choice made for the orientation of the avenue was therefore deliberate and highly symbolic; it influenced the subsequent topography since in this way the position of the last "barque station" was fixed. The choice was an explicit reference to a pattern of orientation strictly related to the royal funerary cult, originated, as mentioned, at Abydos more than 1500 years before and repeatedly applied in the course of the centuries. But why?

To understand this, what is particularly important is the meaning of the topographical axes in the royal necropolises, and especially in the pyramid's fields (Magli 2011a, 2011b). In fact, associated with these axes there is a "movement" in placing subsequent royal tombs to the south west (or simply to the south) of the predecessor's tomb. I have thus proposed (Magli 2014) that the general position of Luxor to the south-west of Karnak, strengthened by the strict inter-cardinal, south of west orientation of the avenue, was due to an explicit, cognitive reference to the "canonical" position of the tomb of a king with respect to his (ideal, or direct) predecessor. Basing on the above astronomical and topographical observations, the "sanctuary of the south" - where the power of the gods was "re-enhanced" and, in a sense, resuscitated - can thus be seen as a sort of gigantic Serdab, the special room where the Opening of the Mouth was performed. The relative disposition of the Luxor temple with respect to Karnak - analogue to the "classic", almost mandatory position for the tomb of the successor to a revered king - thus alludes to the fact that the new king is no one but the "renewed" Pharaoh, who succeeds to himself as well as does the "rejuvenated" Amun of Karnak. Luxor and Karnak, the most sacred places of "Heliopolis of the south" as Thebes is called in many official documents of the period - thus shared the same "dynastic" connection which governed the topographical relationship between Giza and Heliopolis some 1000 years before.

\section{Conclusions}

Sacred architecture or, more generally, sacred space is a simple and natural concept; it is familiar, as Mircea Eliade (1959) once said. This holds also at eastern Thebes: the symbolic relationship between Karnak, the main "house" of Amun-who-hears-the-prayers, and Luxor, the main "house" of Amun as Amenenope, responsible for renovating the Ka of the Pharaoh, was not "esoteric" as many authors tried to claim in the past; on the contrary, it is heightened by a series of references to sacred space concepts which would have been quite familiar to all 
Egyptians capable to read such things. Among these references, the Avenue of the Sphinxes was a key element, for it absolved to a fundamental, albeit symbolic, function. Its role indeed was to establish between the two temples a topographical axis which made explicit reference to dynastically related concepts of rebirth of the Pharaoh as a living God.

\section{References}

Assmann, J. (2003) The Mind of Egypt: History and Meaning in the Time of the Pharaohs Harward Un. Press, NY

Bell, L. (1985) Luxor Temple and the Cult of the Royal Ka Journal of Near Eastern Studies Vol. 44, , pp. 251-294

Belmonte, J.A., and Shaltout, M. (2005) On the Orientation of Ancient Egyptian Temples: (1) Upper Egypt and Lower Nubia J.H.A. 36 p. 273-298

Blyth E. (2006) Karnak: Evolution of a Temple, Routledge, London.

Cabrol A. (2001) Les Voies Processionnelles de Thebes Orientalia Lovaniensia Analecta, Peeters Publishers, London.

Eliade, M, (1959) The Sacred and the Profane: The Nature of Religion, London: Harcourt.

Hawkins G. S. (1974) Astronomical alignements in Britain, Egypt and Peru Philosophical Transactions of the Royal Society of London. Series A, Mathematical and Physical Sciences Vol. 276, No. 1257, 157-167

Lehner, M., (1985) A contextual approach to the Giza pyramids, Archiv fur Orient. 31, 136-158

Magli, G. (2010) Topography, astronomy and dynastic history in the alignments of the pyramid fields of the Old Kingdom; Mediterranean Archaeology and Archaeometry 10, 59-74.

Magli, G. (2011a) The Snefru projects and the topography of funerary landscapes during the 12th Egyptian Dynasty Time and Mind 5, 53-72

Magli, G. (2011b) From Abydos to the Valley of the Kings and Amarna: the conception of royal funerary landscapes in the New Kingdom Mediterranean Archaeology and Archaeometry 11, 2

Magli, G (2014) A Cognitive approach to the Luxor-Karnak relationship Time and Mind, 7, 33-45

Wilkinson, R.H (2003) The Complete Temples of Ancient Egypt Thames and Hudson 


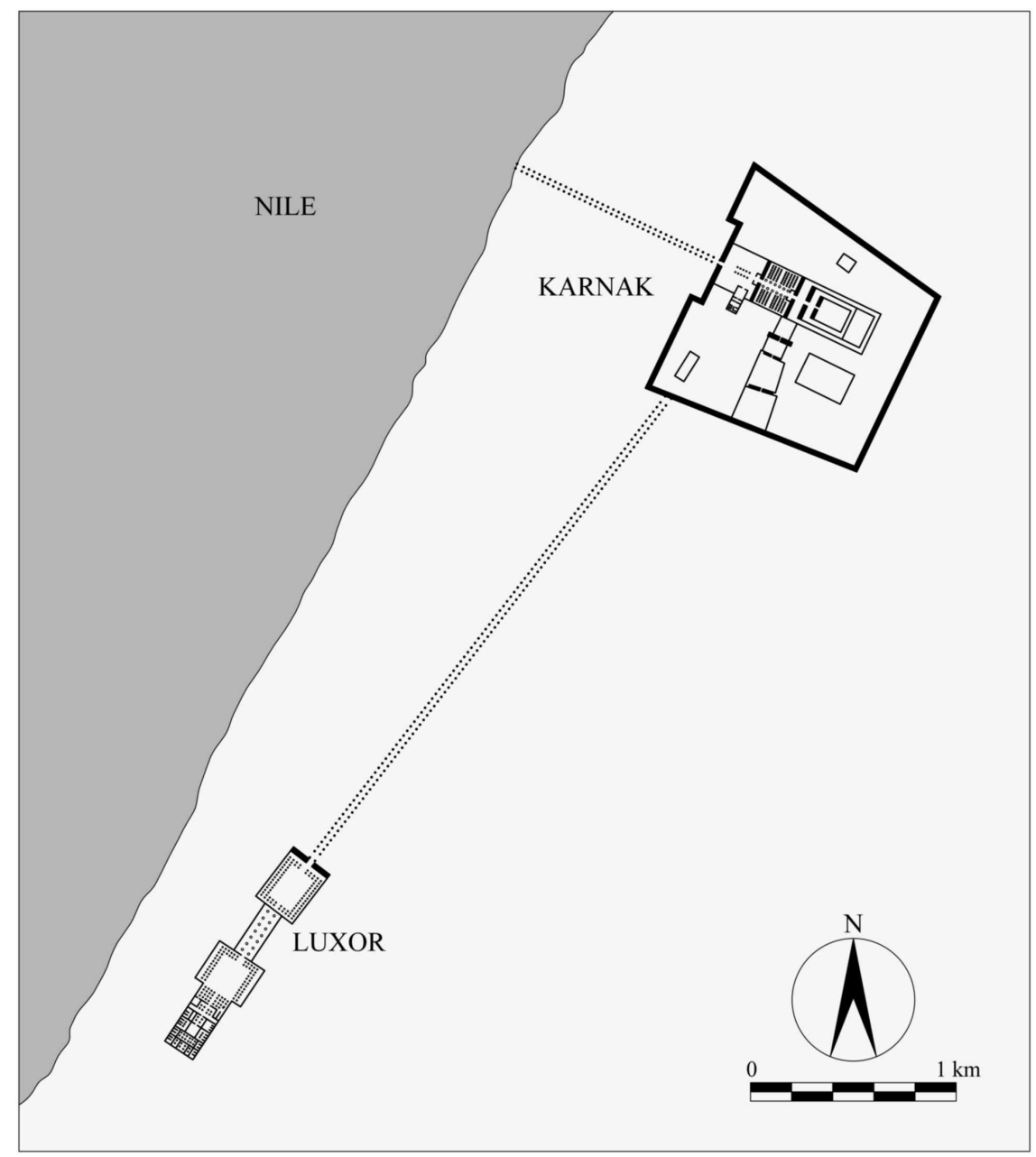

Fig. 1 Plan of the Karnak-Luxor area 


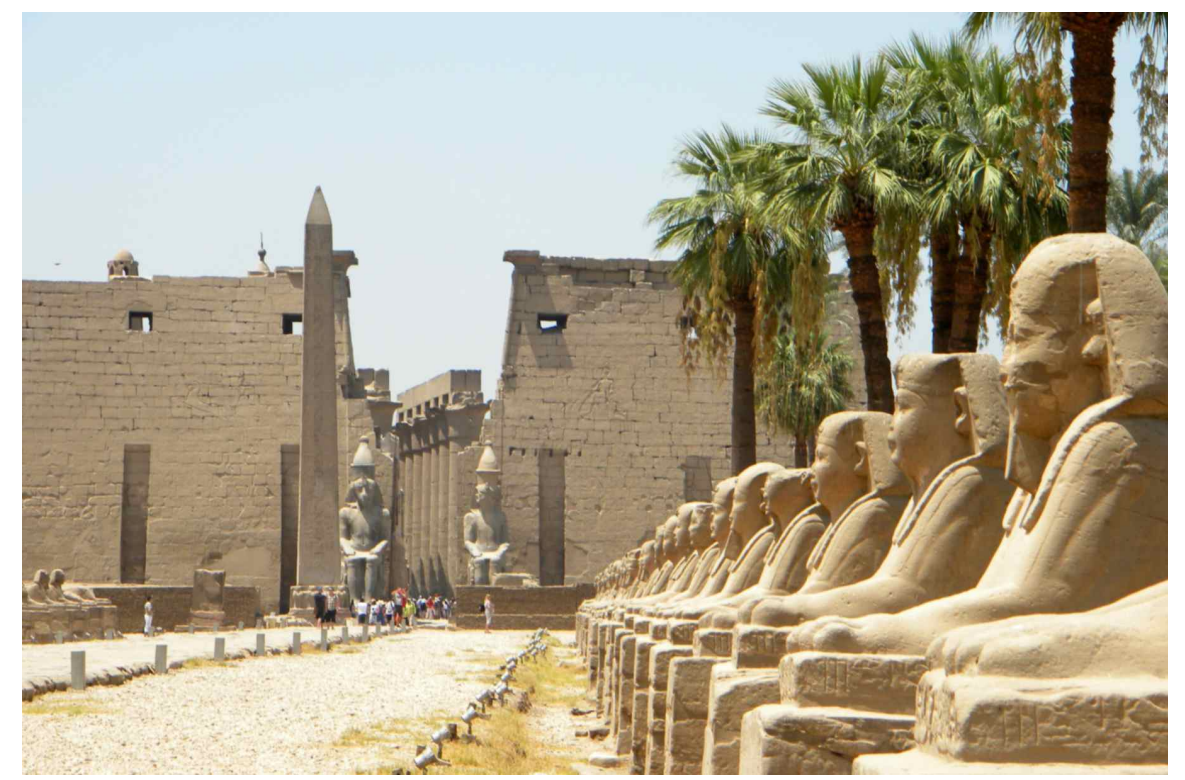

Fig. 2 The final section of the Avenue of the Sphinxes towards Ramesses II' pylon of the Luxor temple (Photograph by the author). 
